\title{
Albina Auksoriūtè
}

Institute of the Lithuanian Language

Vilnius

\section{Current State of Terminology in Lithuania: Scientific Research, Management and Education}

\section{Introduction}

The present article discusses the current situation of terminology in Lithuania, introduces terminological research carried out over the last five years, analyses ways of regulating Lithuanian terms (terminography, creation of term banks and databases, standardisation of terms) and briefly overviews education and teaching of terminology in Lithuania.

The history of written Lithuanian terminology starts in 1547 in Königsberg, which was one of the centres of Lithuanian culture at the time, when the first Lithuanian book was printed. The book was a Lutheran catechism with a short ABC book, some hymns and various other things, prepared by Martynas Mažvydas. The first book is not only a very valuable source of Lithuanian Christian terminology but it also includes terms of linguistics, pedagogy and other fields (Keinys, Auksoriūte, \& Labanauskienè, 2003, p. 59).

Over more than 465 years, Lithuanian terminology has gradually developed in direct relationship to changes of the educational, cultural, economical and political situation of the region. The road towards the contemporary terminology of diverse fields was uneven, with ups and downs as well as stagnation periods. Current terminology formation was started by the national rebirth movement in the second half of the $19^{\text {th }}$ 
century, which culminated in the restoration of the independent state of Lithuania in 1918. In the period 1918-1940, contemporary terminology necessary for all areas of the state was rapidly created, as many publications on science, technology, religion, art, state life and other areas were published. In the early 1920s, the State Commission of Terminology was established with the objective of organizing and managing terminological work; it adopted quite a few terms of law, economics, transport, communications, literary science, and other disciplines (see Keinys et al., 2003, pp. 59-63).

After World War II, Lithuania, annexed to a foreign state, lost the opportunity to autonomously manage its life and develop its language. The development of terminology in religion, military science, communications, transport, and in some fields of science, industry and energy sector was terminated or suspended. However, actual terminological work did not cease. From the 1950s, management of terms of botany, chemistry, physics and other disciplines - initiated before World War II - was continued; yet in many areas of life as well as in terminology the impact of the Russian language was noticeable. In some areas, especially in economics, law, politics, philosophy, state life, Lithuanian terminology followed the patterns of Russian terminology of respective disciplines (see Keinys, 2004, pp. 222-224).

In 1990, after the restoration of the independent state of Lithuania for the second time in the $20^{\text {th }}$ century, the previous terminology management work was continued, with attention turned firstly to the terminology of those fields that were extensively russified. Since 1990 terminology management and organisation work has increased in speed but also the scope of Lithuanian terminology research has extended: in 1994, the annual terminological research journal Terminology appeared, a course in terminology for Lithuanian language students was introduced in universities and preparation of bachelor's and master's theses in terminology began.

\section{Research}

Terminology management is based on theoretical and scientific research into terminology; thus, currently, the development of terminology as a scientific discipline is of special relevance. Heribert Picht, one of the most prominent theorists of terminology, gives a clear definition of the importance of terminology in the modern world:

Science of terminology has meta-status among all other sciences since terminology is a precondition for all kinds of creation of knowledge and its communication, knowledge ordering, knowledge exchange and knowledge proliferation. Science of terminology is not limited to one particular science or group of sciences but it serves all sciences, although some theoretical approaches have to be adapted to the nature of the different sciences (Picht, 2011, p. 24).

Lithuanian terminology research is carried out at the Institute of the Lithuanian Language, at universities and research institutes. 
At the Institute of the Lithuanian Language, the Centre of Terminology operates with the aim of researching Lithuanian terminology and terminography and analysing the functioning of Lithuanian terms of different fields. The researchers of the Centre analyse theoretical problems of the current Lithuanian terminology and terminography (see Gaivenis, 2002, 2014; Kaulakienè, 2014; Keinys, 2005, 2013; Klimavičius, 2005; Mitkevičienè, 2015); explore the history of Lithuanian terminology (see Auksoriūtè, 2004, 2012; Keinys, 2012; Rimkutè-Ganusauskienè, 2015; Umbrasas, 2010; Zemlevičiūté, 2007) and study the development of Lithuanian terms of different fields (see Auksoriūtè, 2015; Kaulakienė, 2009; Stunžinas, 2010; Umbrasas, 2015; Zemlevičiūtè, 2013); undertake terminology ordering in various fields; create, evaluate and standardise new terms (Stunžinas, 2014, 2015; Umbrasas, 2014) (on the terminological work at the Institute of the Lithuanian Language, see Auksoriūte, 2011, pp. 57-64). A number of research papers is published every year. Between 2010-2014, 47 research articles appeared in Lithuanian and foreign academic publications.

Every year, the Centre of Terminology prepares and publishes the research journal Terminologija (Terminology). The first issue of the journal appeared in 1994 and the $22^{\text {nd }}$ issue last year. From the $13^{\text {th }}$ volume onwards, it has been an international journal of Lithuanian and general linguistic terminology with an international board of editors; articles are printed in Lithuanian, English, and Russian. Terminologija is concerned both with the theory and practice of terminology. It deals with theoretical issues, principles and perspectives of terminology, introduces good practice of the development and dissemination of terminology in other countries and presents language and terminology resources. Efforts are made to cover all areas of Lithuanian terminology and to analyse various terminological issues in the European Union documents; education of the academic language is discussed as well as standardisation of terms. The sources of modern Lithuanian terminology and its requirements, mistakes in standardisation and inaccuracies in usage are discussed. The publication contains not only research articles but also reviews, summaries of events held and activities undertaken, annotated bibliographies of the latest editions of terminology dictionaries, foreign terminology news. The journal is aimed not only at those managing terminology but also at users of terminology.

In the recent years, three doctoral theses on Lithuanian terminology have been defended in the Institute of the Lithuanian language: Stunžinas, Robertas. Statybos liaudies terminai (Folk Terms for Building) (2011); Rimkute, Aušra. 1883-1916 metu katekizmu religijos terminai (Religious Terms in 1883-1916 Catechisms) (2012), and Mitkevičienè, Asta. 1918-1940 metu lietuviu literatūros mokslo terminai (Lithuanian Literary Terms in 1918-1940) (2015). Another doctoral theses on terminology was defended by Markas Paura at Vilnius University (Department of Translation and Interpretation Studies) - Savokos kompiuteriu virusas semantinis laukas (The Semantic Field of the Concept Computer Virus) (2014). 
The Centre of Terminology organises scientific conferences on terminology, seminars for specialists, where researches of the Centre give presentations. In 2010-2015, 6 events were held.

The Institute of the Lithuanian Language maintains close relations with terminologists from many countries (Latvia, Hungary, Poland, Germany, Austria, Sweden, Finland, Russia, Belarus, Ukraine, etc.) and is a member of leading international terminology organisations - International Information Centre for Terminology (INFOTERM) and European Association for Terminology (EAFT).

Researchers of the Centre of Terminology also engage in quite a substantial amount of practical terminological work as they cooperate with the Language Commission as experts, participate in the activity of its Terminology Subcommittee, provide expertise and debate on Lithuanian terms included into LTB. Most employees of the Centre of Terminology assist terminological dictionary compilers as linguists-terminologists and provide consultations. They have prepared the explanatory dictionary of terms Skolinti terminai ir ju atitikmenys (Borrowed terms and their equivalents), available on the Internet at http://sta.lki.lt. The website of the Institute of the Lithuanian Language is available at www.lki.lt.

Lithuanian terminological research is carried out not only at the Institute of the Lithuanian Language but also at universities and other research institutions; however, only individual scholars of those institutions engage in terminological research ${ }^{1}$.

\section{Ways of Terminology Management}

There are four distinctive ways of terminology management: terminography, i.e. preparation and publication of term dictionaries; standardisation of terms; creation of term banks and databases; and terminology management through preparation and publishing of academic and other literature, especially textbooks for institutions of higher education (Gaivenis, 2002, p. 63). Three of these ways are discussed in this article: terminography, creation of term banks and databases, and standardisation of terms.

\section{Terminography}

The first half of the $19^{\text {th }}$ century should be considered the beginning of Lithuanian terminography, when the monk Jurgis Ambraziejus Pabrèža (1771-1849) wrote the first manuscript term dictionaries (Dictionarium Botanicum Latino Samogiticum, 1821; Sryje Balsenyyny, 1834; Tayslós augumyynis, 1843). The year 1900 could be regarded as the begin-

1 Among noteworthy researchers at Vilnius University are Nijolè Maskaliūnienė, Markas Paura, Antanas Smetona, Vytautas Magnus University - Erika Rimkutė, Jolanta Kovalevskaité, Agnè Bielinskienè, Klaipeda University - Albinas Drukteinis, Jūratė Lubiené, Šiauliai University - Regina Kvašytė, Lithuanian University of Educational Sciences - Vidas Valskys, Vilnius Gediminas Technical University - Angelè Kaulakienè, Rasuolè Vladarskienè et al. 
ning of printed Lithuanian term dictionaries, when part of J. A. Pabrezža's manuscript Taislius Augyminis (The System of Plants) titled Botanika arba Taislius auguminis (Botany, or the System of Plants) was issued in America. In Lithuania, the first dictionary was published in 1907 - Žolynas. Lietuvos augalu žodynas ir augaly taislas (Herbs. The Dictionary of Lithuanian Plants and the System of Plants) by Povilas Matulionis (1860-1932). Between 1900-1940, 13 term dictionaries of different fields were published in Lithuania - mostly small-scale Russian-Lithuanian and Lithuanian-Russian sets of terms.

Between 1941-1989 not only term dictionaries but also fundamental scientific works were prepared and published, such as Lietuvos TSR fizine geografija (Physical geography of the Lithuanian Soviet Socialist Republic) (1958-1965, 2 vol.), Lietuvos TSR flora (Flora of the Lithuanian Soviet Socialist Republic) (1958-1980, 6 vol.), Lietuviu kalbos gramatika (Lithuanian grammar) (1965-1976, 3 vol.), encyclopaedias, monographs, collected scientific works. Over this nearly fifty-year period, more than 170 dictionaries of different fields were compiled and published, among them term dictionaries with other language equivalents predominated. It is characteristic of Lithuanian terminography of the period 1941-1989 that both explanatory and translation term dictionaries usually provided equivalents in Russian, equivalents from other languages were scarce (see Klimavičius, 2003, pp. 9-32).

In terms of publishing, the most productive period of Lithuanian terminography is from 1990 up to date. In total, more than 420 term dictionaries and special encyclopaedias of different fields were published between 1990-2013. Almost half of term dictionaries are explanatory or translation-explanatory dictionaries. The recent growth of terminographical work has been helped by state support. Before 1996, the Department of Terminology of the Institute of the Lithuanian Language used to approbate term dictionaries and standards; since 1996, approbation and organisation of compilation of term dictionaries was taken over by the Language Commission.

It should be emphasized that the number of term dictionaries published in Lithuania is quite substantial - over 600; term dictionaries of some fields have even been published several times. However, properly prepared good quality explanatory term dictionaries are not available across all subject areas (explanatory term dictionaries of law, economics, construction, mathematics, medicine, history and other disciplines are lacking). The Language Commission has attempted to improve this situation by inviting tenders for preparation of specific dictionaries and by funding their preparation. It should be noted that lately the number of term dictionaries being compiled has decreased the average number of term dictionaries published yearly in the period 2004-2007 was about 20, in 2009-2012 this number stood at around 10, in 2015 - 15 dictionaries $^{2}$.

${ }^{2}$ Out of the term dictionaries published in 2009-2013, the following are evaluated as properly prepared: Penkiakalbis aiškinamasis metrologijos terminu žodynas (2009) - Five Languages Explanatory Dictionary of Metrology (Electronic source); Aiškinamasis elektrotechnikos terminų žodynas (2010) - 
The analysis of terminology management in Lithuania should acknowledge the state institution important for standardisation, management and dissemination of Lithuanian terms - the Language Commission which is entitled to evaluate and approve the most important works of language standardising. The Language Commission on a collegial basis decides on issues pertaining to the implementation of the Law on the State Language, language policy, management and standardisation of the Lithuanian language, etc. The Language Commission evaluates term dictionaries, term standards and approbates sets of terms of legal acts and drafts thereof, supports preparation of term dictionaries.

There are 8 subcommittees of the Language Commission; one of them is the Terminology Subcommittee that deliberates on term dictionaries, term standards, legal acts, the Language Commission recommendations, terminological enquiries of the European Union institutions received via the "one-stop-shop" system, and other terms. As pointed out in the Language Commission report, in 2014, 50 meetings of the Terminology Subcommittee of the Language Commission were held; it discussed 1,336 term entries furnished by state institutions to LTB, 4 manuscripts of term dictionaries, 1 revised and supplemented edition of a dictionary, 2 draft Lithuanian term standards, 1 revised standard, terminological enquiries of the European Union Institutions received via the "one-stop-shop" system, names of Lithuanian botanical and zoological nomenclature, other issues on terminology and replacement of foreign words with Lithuanian equivalents (see Valstybinè lietuvių kalbos komisija, 2015).

\section{Creation of Term Banks and Databases}

At the end of 2003, the Law on LTB was adopted to regulate the creation, management and funding of LTB. Thus, for 12 years terminology management in Lithuania has been regulated by the law and on this basis LTB was created and is administered by the Language Commission.

The structure of the term bank, technical data of the information system, requirements and other issues are defined in the Methodology of LTB, stating as follows:

The purpose of the Term Bank is to ensure consistent usage of the approved terms of the Lithuanian language, particularly those used in legal acts of the Republic of Lithu-

Explanatory Dictionary of Electrotechnical Terms, 1078 pp., 10,400 terms; Žemés ükio augalu selekcijos ir sèklininkystés terminu žodynas (2010) - Dictionary of Agricultural Plant Selection and Seed-Growing, 337 pp., 3,000 terms; Informatikos, kompiuterijos ir telekomunikaciju anglu-lietuvių kalbuz žodynas (2011) - English-Lithuanian Dictionary of Informatics, Computer Science and Telecommunications), 831 pp., 38,000 Lithuanian terms; Adiafora: Aiškinamasis elektrotechnikos terminu žodynas (2012) Explanatory Dictionary of Electrotechnical Terms (Electronic source), 10,000 terms; Lingvodidaktikos terminy žodynas (2012) - Dictionary of Linguadidactic Terms, 233 pp.; Aiškinamasis elektrotechnikos ir elektronikos gaminiu terminu žodynas (2014) - Explanatory Term Dictionary of Electrotechnics and Electronic Products, 4,200 terms. 
ania, to create a common information system for various public authorities, which could be accessed by and receive data from other individuals and organizations and which could be used freely by specialists in different fields not only in Lithuania but also in other countries ("Lietuvos Respublikos terminų banko metodika", n.d.).

Ministries and their subordinate departments and services, government authorities, the Parliament of the Republic of Lithuania and other state institutions are authorised to store and manage terms of their fields in the Term Bank. Terminology Commissions have been established in different state institutions, initially responsible for making an inventory of terms of legislation in force, editing term entries and presenting them to LTB; subsequently, the focus moved to coordination of draft legislative terms with the Language Commission and adding them into LTB. The terms deliberated by the Terminology Subcommittee and approved by the Language Commission are added to LTB with a mark approved. In addition to legislative terms, dictionaries that receive positive assessment from the Language Commission are added to the Term Bank; these are mostly explanatory dictionaries whose terms have a mark recommended. Data from 37 term dictionaries are available in the Term Bank.

In $2014,1,288$ entries of used or recommended legislative terms, also 5 recommended and 4 deprecated entries of terms of legislative or other documents were included in LTB. In addition to legislative terms provided by state institutions, 1,530 Lithuanian names for botanical and zoological nomenclature recommended or positively assessed in the resolutions of the Language Commission were entered into LTB, consisting of 1,025 plant names, 471 insect names, and 34 fish names.

As LTB data increase, so does the number of LTB users and frequency of using the term search. In 2012, about 700,000 enquiries were recorded, while in 2013 the total number thereof since the establishment of LTB exceeded 3 million (see Umbrasas, 2013, pp. 96-122 on the conception, legal basis, structure, enquiry statistics).

LTB contains over 237,000 term entries. At the end of 2016, LTB contained 12,772 entries of approved, 223,858 recommended, and 1,169 deprecated terms.

The Term Bank is currently the most reliable and universal source of Lithuanian terminology available on the Internet which can be useful for scientists, editors, translators and other specialists working with terminology or interested in terminology (Umbrasas, 2013, p. 122).

LTB is available at http://terminai.vlkk.lt

Two more term databases containing Lithuanian terminology sources are worth mentioning: IATE and EUROTERMBANK.

IATE (Inter-Active Terminology for Europe) is an interinstitutional European Union term database launched in 1999. In 2004, employees of EU institutions started using it. IATE includes all databases of translation services of the European Union that were previously developed on an individual basis (e.g., Eurodicautom, TIS, 
Euroterms, CDCTERM, and Euterpe). This database was made public in June 2007. The term database is continually updated with terms from EU legislation, names of institutions, organisations, preformulated phrases in legislation, etc. Most IATE entries are multilingual - usually, terms are given in 23 official EU languages, terms of certain fields are also given in Latin. In addition to terms, IATE provides much other data, such as field (domain), definition, sources, context, notes, systemic links to other terms, reliability and acceptability information, etc. At the beginning of 2015, this database contained 1.5 million multilingual term entries, over 8.7 million terms and over 57,000 Lithuanian terms. IATE is available at http://iate.europa.eu/.

EUROTERMBANK is a centralised term bank of the new EU members available via the Internet and linked with other national and international term banks and resources. All terms are classified according to subject areas based on Eurovoc - an official multilingual European Union thesaurus (this bank provides version 4.2 thereof). There are multiple term search possibilities: one can choose language, subject area, search for all forms of the term, search in definitions and explanations or in external databases. In addition, there is a possibility to find terms in the bank according to their status, i.e. approved terms. Term entries given in the EUROTERMBANK are compiled from different sources; however, the original source is always indicated (see Auksoriūtè, 2008, pp. 12-19).

EUROTERMBANK contains over 710,000 term entries consisting of more than 2.6 million terms in different languages, provides over 221,000 definitions, and includes 33 languages in total. EUROTERMBANK is linked with 4 external databases: TermNet.lv (Terminology database of the Latvian Academy of Science), OLSTEN (Open Dictionary of Scientific Terminology of the Agricultural Academy in Szczecin), MoBiDic (Hungarian term database), and IATE. There are more than 78,000 Lithuanian terms and their equivalents in other languages from 11 sources included in this term bank. EUROTERMBANK is available at www.eurotermbank.com.

In addition to large electronic databases and banks, smaller term databases exist. Recently published term dictionaries usually have electronic versions; thus, some authors provide them on the Internet. In addition, Lithuanian terminology resources are available on the websites of different projects and institutions (www.raštija.lt; http://www3.lrs.lt/pls/ev/ev.main; http://www.zodynai.ff.vu.lt., etc.).

\section{Standardisation of Terms}

The Lithuanian Standards Board is a national standardisation institution established in 1991 that forms technical committees for preparation of Lithuanian standards and coordinates their activity, sets the order of adoption of international, European and foreign standards as Lithuanian, approves, publishes and disseminates Lithuanian standards. As for Lithuanian terminology, it is important that the Standards Board prepares Lithuanian standards of terms and submits them to the Language Com- 
mission for evaluation. In 2010, the Language Commission evaluated two, in 2011 and 2012 - five each, 2013 - one, 2014 - four Lithuanian standards of different fields.

In 1996, the Technical Committee 37 Terminology (LST TK 37 Terminologija) was established; its field of activity is standardisation of terminology, management of other linguistic and content resources, terminography, lexicography and principles and methods of computer-aided terminology management. Unfortunately, due to lack of funding the activity of LST TK 37 Terminologija was suspended in May 2009 and the Terminology Commission was formed solely from employees of the Standards Board; this Commission deliberates terms of the standards.

Since 2000, the Lithuanian Standards Board has been maintaining a database of standardised terms. Currently, it contains around 64,000 terms. This database is freely available for users at the website of the Lithuanian Standards Board at www.lsd.lt.

\section{Terminological Education}

Since terminology today is established as a field of knowledge with scientific research and corresponding applications, it fulfils the requirements of an academic discipline which again can be considered the precondition for courses of studies and training (Picht, 2009, p. 18).

The terminology course for philologists is lectured at many universities of Lithuania. Terminology is taught as a compulsory subject under the master's studies programme Language for Specific (Legal) Purposes at Vilnius University; under the programme Translation and Interpretation Studies, terminology and terminography are taught as compulsory, legal terminology - as an optional subject; under the programme General Linguistics, terminology is offered as an optional subject. At Vilnius University, Kaunas Faculty of Humanities, terminology and language planning is lectured as a compulsory subject under the master's studies programme Lithuanian Linguistics. At the Lithuanian University of Educational Sciences, the master's studies programme Lithuanian Philology includes a course on terminology, and bachelor students specialising in terminology management - future language editors - are lectured on terminology management. At Vytautas Magnus University, a course on terminology and terminography is included in the master's studies programme Applied Lithuanian Linguistics. A lecture on terminology is included in the Lithuanian Lexicology course for bachelor students. Šiauliai university has also included a course on terminology into the master's studies programme Lithuanian Linguistics. Klaipeda university is the only one that teaches this subject under a bachelor's studies programme Lithuanian Philology and Language Management.

Bachelor's and master's theses on terminology are prepared at universities. For instance, in 2010-2014, students studying under the Translation and Interpretation 
Studies programme at Vilnius University completed 13 master's theses on terminology. Since 2010, 9 bachelor's theses on terminology were defended at Šiauliai University, 4 bachelor's theses and 2 master's theses - at the Lithuanian University of Educational Sciences. There were no master's and bachelor's theses written at the Lithuanian Language Department of Vytautas Magnus University; however, at other departments of the Faculty of Humanities, mostly under the Applied English Philology programme, 8 master's theses were defended. At Klaipeda University, in 2010-2015, 10 bachelor's theses on seafaring terminology and one master's thesis on mycology terms were prepared ${ }^{3}$.

It is praiseworthy that at Lithuanian universities philologists learn the fundamentals of terminology. However, no Lithuanian terminology textbook has been published, the lecturers prepare their own lecturing material/notes.

At many Lithuanian universities, students of other non-philological disciplines are taught a course on language for specific purposes which, in addition to other subjects, analyses key terminological and terminographical issues, as it is of utmost importance for students to get acquainted with the basics of terminology and learn grammatically correct terms of their field at university already. In order to ensure education on academic language, the Language Commission supports this course in the institutions of higher education.

\section{Conclusions}

In most areas, Lithuanian language terms are managed considerably well; the principles of term creation and ways of their management, directions of organisation of terminological work and activities have settled; terminological work is carried out in cooperation with specialists and terminologists working at different Lithuanian and European Union institutions.

Most terminological research is carried out at the Centre of Terminology of the Institute of the Lithuanian Language, whereas at some Lithuanian universities terminological research is carried out by individual scholars only. Recent terminological research does not cover all areas of terminology, theoretical research on current Lithuanian terminology is scarce.

In recent years, the growth of Lithuanian terminography emerging after the restoration of independence of Lithuania has slowed down, even though the Language Commission continues support for preparation of term dictionaries. Since 1990, 420 term dictionaries and specialised encyclopaedias of different fields and varying in scope have been published; yet properly prepared explanatory term dictionaries of some fields are still missing.

3 The author is grateful for the information to Jolanta Kovalevskaite, Regina Kvašyte, Jūratė Lubienè, Vidas Valskys and Rūta Bagužytè. 
LTB is the largest and most reliable source of standardised Lithuanian terms freely available on the Internet, providing not only legislative terms approved by the Language Commission but also terms from the most recent explanatory term dictionaries. Resources of Lithuanian terms are available at the websites of different projects and institutions as well as international databases (IATE, EUROTERMBANK). Lithuanian Standards Board maintains the database of standardised terms that is freely available for users on the website of the Board.

In Lithuania, terminology is an academic discipline - a terminology course for philologists is taught at many universities, bachelor's and master's theses on terminology are written, and many universities teach students of non-philological disciplines a course in language for specific purposes, which analyses issues of terminology and terms. However, there has been no Lithuanian terminology textbook published for institutions of higher education.

The institutions of higher education, particularly universities of non-philological profile, still give terminology insufficient attention. University students should not only be introduced to the basics of terminology but also encouraged to take an interest in the Lithuanian terms of their discipline, as they are the ones that will have to carry out the terminological work in the future.

\section{Bibliography}

Adiafora: Aiškinamasis elektrotechnikos terminu žodynas [CD-ROM]. (2012). Kaunas: Technologija.

Aiškinamasis elektrotechnikos ir elektronikos gaminiu terminu žodynas. (2014). Vilnius: Mokslo ir enciklopedijų leidybos centras.

Aiškinamasis elektrotechnikos terminu žodynas. (2010). Kaunas: Technologija.

Auksoriūtè, A. (2004). Neaiškios darybos L. Ivinskio Prigimtūmenès naujadarai. In S. Keinys (Ed.), Terminologijos istorijos ir dabarties problemos: Kazimierui Gaiveniui atminti (pp. 127-149). Vilnius: Lietuviu kalbos instituto leidykla.

Auksoriūté, A. (2008). EUROTERMBANK - naujųjų ES narių terminų bankas. Santalka. Filologija. Edukologija [Coactivity: Philology, Educology], 16(2), 12-19. http://dx.doi. org/10.3846/1822-430X.2008.16.2.12-19

Auksoriūtè, A. (2011). Terminology work in Lithuania. In Terminology for Europeans (and beyond): Proceedings of the International Symposium on Terminology Service Centres (pp. 57-64). Gent: Academia Press.

Auksoriūtè, A. (2015). Naujieji dekoratyvinių augalų genčių vardai. Terminologija, (22), 61-77.

Auksoriūtè, A. (Ed.). (2012). Priešaušrio mokslas, kultūra ir švietimas: Lauryno Ivinskio 200-osioms gimimo metinems. Vilnius: Lietuvių kalbos institutas. 
Gaivenis, K. (2002). Lietuviu terminologija: teorijos ir tvarkybos metmenys. Vilnius: LKI leidykla.

Gaivenis, K. (2014). Rinktiniai raštai. Vilnius: Lietuvių kalbos institutas.

Informatikos, kompiuterijos ir telekomunikacijų anglu-lietuvių kalbų žodynas. (2011). Vilnius: Mokslo ir enciklopedijų leidybos centras.

Kaulakienè, A. (2009). Lietuviu fizikos terminijos raida. Vilnius: Technika.

Kaulakienè, A. (2014). Terminologija. Terminografija. Terminija. Vilnius: Technika.

Keinys, S. (2004). Terminologijos raida, būklè, vaidmuo ir uždaviniai ị XXI amžių įžengus. In S. Keinys (Ed.), Terminologijos istorijos ir dabarties problemos: Kazimierui Gaiveniui atminti (pp. 219-239). Vilnius: Lietuvių kalbos instituto leidykla.

Keinys, S. (2005). Dabartine lietuvių terminologija. Vilnius: Lietuvių kalbos instituto leidykla.

Keinys, S. (2012). Lietuvių terminologijos raida. Vilnius: Lietuvių kalbos institutas.

Keinys, S. (2013). Dèl mokslo terminų vienareikšmiškumo supratimo. Terminologija, (20), 47-55.

Keinys, S., Auksoriūtè, A., \& Labanauskienè, S. (2003). Lithuanian terminology on the eve of new century. In Terminology and Technology Transfer in the Multilingual Information Society: Proceedings of the $2^{\text {nd }}$ International Conference on Terminology. In Commemoration of E. Drezen's $110^{\text {th }}$ Anniversary (pp. 59-64). Riga, 21-25 October, 2002. (IITF-Series 11). Vienna: Term Net Publisher.

Klimavičius, J. (2003). Lietuvių terminografija: Praeities bruožai, dabarties sunkumai ir uždaviniai. Terminologija, (10), 9-32.

Klimavičius, J. (2005). Leksikologijos ir terminologijos darbai: Norma ir istorija. Vilnius: Lietuvių kalbos instituto leidykla.

Lietuvos Respublikos terminų banko metodika. (n.d.). Retrieved 9 July 2015, from http://www. vlkk.lt/vlkk-nutarimai/nutarimai/del-lietuvos-respublikos-terminu-banko-metodikospatvirtinimo

Lingvodidaktikos terminų žodynas. (2012). Vilnius: Vilniaus universiteto leidykla.

Mitkevičienè, A. (2015). Kai kurie terminų sinonimijos aspektai. Terminologija, (22), 39-60.

Penkiakalbis aiškinamasis metrologijos terminų žodynas [CD-ROM]. (2009). Vilnius: Mokslo ir enciklopedijų leidybos centras.

Picht, H. (2009). The seven pillars of terminology. Terminologija, (16), 8-22.

Picht, H. (2011). The science of terminology: History and evolution. Terminologija, (18), 6-26.

Rimkutè-Ganusauskienè, A. (2015). 1800-1882 metų katekizmų religijos terminai. Kaunas: Vytauto Didžiojo universitetas; Vilnius: Versus aureus.

Stunžinas, R. (2010). Statybos liaudies ir mokslo terminijos bendrybès ir skirtybės. Terminologija, (17), 42-53.

Stunžinas, R. (2014). Ekologizavimas, žalinimas ir kiti angl. greening atitikmenys Europos Sąjungos institucijų dokumentuose. Terminologija, (21), 111-130.

Stunžinas, R. (2015). Tvarumas, darnumas, tausumas ir kiti angl. sustainability atitikmenys Europos Sąjungos institucijų dokumentuose. Terminologija, (22), 110-126. 
Umbrasas, A. (2010). Lietuviu teisés terminija 1918-1940 metais: Pagrindiniu kodeksu terminai. Vilnius: Lietuvių kalbos institutas. (Opera Linguistica Lithuanica, 11).

Umbrasas, A. (2013). Lietuvos Respublikos terminų bankas: 10 metų po įstatymo priemimo. Terminologija, (20), 96-122.

Umbrasas, A. (2014). Motininè ịmonè ir dukterinė įmonè: Nuo žodynų iki teisès aktų. Terminologija, (21), 90-110.

Umbrasas, A. (2015). Jūra biologijos nomenklatūroje. Terminologija, (22), 78-97.

Valstybinè lietuvių kalbos komisija. (2015). 2014 metų veiklos ataskaita. Retrieved 9 July 2015, from http://www.vlkk.lt/media/public/file/Veiklos_ataskaitos/VLKK_ataskaita_2014.pdf

Žemès ūkio augalu selekcijos ir sèklininkystès terminų žodynas. (2010). Vilnius: Inforastras.

Zemlevičiūtè, P. (2007). Terminologinè medicinos leksika lietuviškuose 1738-1831 metų Prūsijos valdžios įsakuose. Archivum Lithuanicum, 9, 121-182.

Zemlevičiūtè, P. (2013). Pirmasis Lietuvos medicinos mokslo žurnalas ir lietuviškoji medicinos terminija. Terminologija, (20), 142-160.

\section{Aktualny stan terminologii na Litwie: badania naukowe, zarządzanie informacją i edukacja}

\section{Streszczenie}

Artykuł omawia aktualny stan terminologii na Litwie, przedstawia badania naukowe nad zasobami terminologicznymi prowadzone w okresie minionych pięciu lat, analizuje sposoby zarządzania terminami w języku litewskim, a także zawiera zwięzły przegląd tematyki dotyczącej kształcenia i nauczania w zakresie terminologii na Litwie.

Główną placówką zajmującą się badaniami nad terminologią w języku litewskim jest Instytut Języka Litewskiego. Ponadto badania takie prowadzone są także na uniwersytetach i w innych ośrodkach badawczych. Największy udział w badaniach terminologicznych ma Zakład Terminologii w Instytucie Języka Litewskiego, który prowadzi prace nad terminologią litewską i terminografią, a także analizuje użycie litewskiego słownictwa specjalistycznego w poszczególnych dziedzinach.

$\mathrm{W}$ artykule omówiono trzy metody zarządzania zasobami terminologicznymi: terminografia, powoływanie banków terminów i baz danych oraz standaryzacja terminów i pojęć.

Liczba słowników terminologicznych opublikowanych na Litwie jest dość znaczna, jest ich obecnie ponad 600. Najwięcej publikacji pochodzi z okresu po roku 1990. Począwszy od 1990 do 2013 r. ukazało się drukiem ponad 420 słowników i specjalistycznych encyklopedii terminologicznych. 
Główną i najważniejszą bazą terminów na Litwie jest Terminologiczna Baza Republiki Litewskiej (lt Lietuvos Respublikos terminu bankas, dalej: LTB), powstała w 2004 r. Została ona utworzona jako wspólny informatyczny system instytucji państwowych pod patronatem Państwowej Komisji Języka Litewskiego (dalej: Komisja Języka). W LTB znajduje się ponad 237000 haseł terminologicznych.

Artykuł omawia dalej kolejne dwie bazy danych, które zawierają litewskie źródła terminologii, a mianowicie IATE i EUROTERMBANK. Litewska Rada Standaryzacji oprócz innych prac przygotowuje litewskie standardy terminów i przedstawia je Komisji Języka do oceny. Od roku 2000 Litewska Rada Standaryzacji tworzy bazę standaryzowanych terminów, która aktualnie obejmuje 64000 haseł.

$\mathrm{Na}$ Litwie terminologia istnieje także jako odrębna dyscyplina akademicka. $\mathrm{Na}$ wielu uniwersytetach $\mathrm{w}$ programie studiów prowadzone są przez filologów zajęcia z tego zakresu. Na licznych uczelniach studenci kierunków niefilologicznych mają wykłady w zakresie stosowania terminów specjalistycznych, obejmujące kwestie terminologiczne i dotyczące zasobu pojęć.

Słowa kluczowe: terminologia naukowa; terminologia litewska; zarządzanie zasobami terminologicznymi; terminografia; bank terminów; naukowe badania terminologiczne; kształcenie w zakresie terminologii

\title{
Current State of Terminology in Lithuania: Scientific Research, Management and Education
}

\begin{abstract}
The article discusses the current state of terminology in Lithuania, presents terminological research carried out in the last five years, analyses ways of Lithuanian terminology management, and briefly overviews terminological education and teaching in Lithuania.

Lithuanian terminological research is mostly carried out at the Institute of the Lithuanian Language and at universities and other research institutes. The largest part of terminological research is carried out at the Centre of Terminology of the Institute of the Lithuanian Language, which researches Lithuanian terminology and terminography, analyses the use of Lithuanian terminology in different fields.

Three ways of terminology management are discussed: terminography, creation of term banks and databases and standardisation of terms.

The number of term dictionaries published in Lithuania is rather considerable over 600. The most productive period for publishing term dictionaries is from 1990
\end{abstract}


up to date. Between 1990-2013 more than 420 term dictionaries and special encyclopaedias were published.

The main and most important terminology database in Lithuania is the Term Bank of the Republic of Lithuania (lt Lietuvos Respublikos terminu bankas, further - LTB), initiated in 2004. This bank is created as a common information system of state institutions administered by the State Commission of the Lithuanian Language (further - Language Commission). There are more than 237,000 term entries in LTB. The article discusses two more terminology databases containing Lithuanian terminology sources - IATE and EUROTERMBANK. The Lithuanian Standards Board, in addition to other work, prepares Lithuanian standards of terms and offers these terms to the Language Commission for evaluation. Since 2000, the Lithuanian Standards Board has been creating a database of standardised terms which currently contains about 64,000 terms.

In Lithuania, terminology also exists as an academic discipline; at many universities, philologists are offered a course in terminology. At many universities, students of other non-philological disciplines are taught a course in language for specific purposes, which covers matters of terminology and terms.

Keywords: terminology science; Lithuanian terminology; terminology management; terminography; term bank; scientific terminological research; terminological education

Correspondence: Albina Auksoriūtė, Institute of the Lithuanian Language, Vilnius, e-mail: albinaa@lki.lt

Support of the work: This work was supported by a core funding for statutory activities from Institute of the Lithuanian Language.

Competing interests: The author is a reviewer of this journal, but has not reviewed any texts in this volume. 